\title{
Despite the Virus. A Survey with Parents on Early Childhood Education Services and Families, in Covid-19
}

\author{
Alessandra Gigli, Marco Trentini ${ }^{2,3}$
}

\begin{abstract}
The paper presents a survey that involved a sample of 178 parents of children attending the infant-toddler centers and preschools of the Municipalities of Bassa Romagna, in the Province of Ravenna (Emilia-Romagna, Italy), between December 2020 and January 2021. The survey had the following aims: to deepen the knowledge of parents' opinions on various aspects of the impact of the pandemic on daily life and parental functions; to monitor any difficulties their children may have; to understand how much the actions taken, to adapt school attendance in the pandemic period, have met with family satisfaction and have positively pursued the educational alliance. Another objective of the research was to involve the professionals of these educational services in reflecting on the results (already returned with a research report and a training seminar) and to organize opportunities for reflection with the same parents who participated in the survey.
\end{abstract}

Keywords: Covid-19, family, parents, educational alliance, early childhood education and care.

\begin{abstract}
Il contributo presenta una ricerca che ha coinvolto un campione di 178 genitori di bambini frequentanti i nidi e le scuole dell'infanzia dei Comuni della Bassa Romagna, in provincia di Ravenna (Emilia-Romagna) tra dicembre 2020 e gennaio 2021. La rilevazione ha avuto i seguenti scopi: approfondire la conoscenza delle opinioni dei genitori su vari aspetti dell'impatto della pandemia sulla vita quotidiana e sulle funzioni genitoriali; monitorare eventuali difficoltà dei figli; comprendere quanto le azioni intraprese, per adattare la frequenza scolastica nel periodo pandemico, abbiano riscosso la soddisfazione
\end{abstract}

${ }^{1}$ Associate Professor in General and social Pedagogy, at the Department of Education Studies 'Giovanni Maria Bertin' - University of Bologna.

${ }^{2}$ Associate Professor in Economic sociology and Sociology of work, at the Department of Education Studies ‘Giovanni Maria Bertin' - University of Bologna.

${ }^{3}$ This paper is the result of a coordinated and joint work of the two Authors. Specifically: Alessandra Gigli edited Introduction, parr. 1, 2, 3.1, 3.2, 4, Conclusion and implications; Marco Trentini edited par. 3.3 and carried out the data analysis (from now on, unless otherwise specified, footnotes are edited by this paper's Authors, Editor's Note). 
delle famiglie e abbiano perseguito positivamente l'alleanza educativa. Un altro obiettivo della ricerca è stato coinvolgere i professionisti di tali servizi educativi nella riflessione sui risultati (già restituiti con report di ricerca e seminario formativo) e di organizzare occasioni di riflessività con gli stessi genitori partecipanti al sondaggio.

Parole chiave: Covid-19; famiglia, genitori, alleanza educative, educazione e cura della prima infanzia.

\section{Introduction}

Starting in March 2020, Covid-19 hit Italy particularly hard with record-breaking rates of contagion and deaths; in the following three months, the safety measures issued by the government to contain the health crisis imposed the total closure of businesses, educational and school services, many public services (some of which provided only remote services); restrictions on the free movement of citizens and physical distancing measures were issued too. The so-called "lockdown" relegated almost the entire population indoors: exits were permitted only for health reasons, emergencies, or to go to work. The government decrees facilitated telecommuting: it is estimated that throughout the 2020s there was a substantial increase in work from home, previously little used in Italy (Istat, 2020a).

Serious signs of economic crisis together with the risk of permanent closure of many medium and small businesses have caused a loss the income for many families (DOXA, 2020): despite the income compensation measures undertaken by the Italian government, «one in ten Italian families is still at risk of a liquidity crisis and workers in the sectors that were suspended in March and April, particularly among employees, still record significant losses» (MEF, 2020, p. 1)

The impact of the pandemic is not only relative to the economic sphere, but also overwhelmingly invests the relational, cultural, and existential dimensions of the entire population, with a greater effect on the most disadvantaged ones, on young people, and family dynamics. Almost a year after the outbreak, the situation has slightly improved in terms of health, but the spread of the virus is still very high and the healthcare system is in continuous distress: for this reason, from October 2020 to February 2021, there has been an alternation between peri-

${ }^{4}$ From now on, unless otherwise specified, the translations of Italian quotes into English are edited by this paper's Authors, Editor's Note. 
ods of relaxation of the restrictive measures and periods of lockdown. In the same period, only primary schools, middle schools, and early childhood education services were open (except for quarantine situations due to outbreaks): adolescents over 14 years of age (attending high school) were forced to distance learning (in Italian called "Didattica a Distanza": $\mathrm{DaD}^{5}$ ) with severe limitations to social and relational life, extended to the entire citizenry.

In this long period, feelings of fatigue, anxiety, pessimism, and uncertainty about the future have further increased: what the WHO (2020) has called pandemic-fatigue has spread. The implications of this global phenomenon, which is still evolving, are complex and difficult to summarize in general terms. Thus, respecting this complexity, we believe that at this stage we could try to understand some specific situations and strive to identify both the critical elements and the evolutionary prospects inherent in the crisis.

This work is situated both in the disciplinary field of family pedagogy and in the strand of studies that deal with the educational alliance between educational services and families, and it was developed within the research activities of the Center for Educational Research on Childhood and Families (CREIF) ${ }^{6}$ of the Department of Education Studies 'Giovanni Maria Bertin' of the University of Bologna.

The goals of this paper are mainly to capture the point of view of parents ${ }^{7}$ of boys and girls aged 0-6 regarding the effects that the pandemic has had on their family environment and to identify some practices adopted in early childhood education services ${ }^{8}$ to facilitate the relation-

${ }^{5}$ In Italy, we use $\mathrm{DaD}$ for distance learning actions; LEAD or READ for actions aimed at maintaining the educational relationship, even if not didactic. For further information on LEAD, see the Ministerial Document on LEAD: MIUR (2020), Commissione Infanzia e sistema Integrato Zero-sei. ORIENTAMENTI PEDAGOGICI SUI LEAD. LEGAMI EDUCATIVI A DISTANZA (text available on https://www.miur.gov. it/orientamenti-pedagogici-sui-legami-educativi-a-distanza-per-nido-e-infanzia-lead-; last access: 20.2.21).

${ }^{6}$ For more details see https://centri.unibo.it/creif/it (last access: 9.3.21).

${ }^{7}$ To avoid making the text heavier, while respecting gender differences, in this article the terms: authors, educators, teachers, parents, children, children, are expressed in the masculine plural but include the declination of the terms in the masculine and feminine (e.g.: educators/educators, collaborators/collaborators, authors/authors).

${ }^{8}$ In this paper, the term early childhood education services (ITA: servizi educativi per la prima infanzia) refers to those for the 0-6 years age group, comprehensive of crèches (ITA: nidi d'infanzia), and preschools (ITA: scuole dell'infanzia). The term "school services" refer to schools of all levels. 
ship with families in the period of reopening (from September 2020 to the present).

\section{Theoretical Framework}

As previously mentioned, the research is located in the strand of studies of family pedagogy which in our country has a very deep and established tradition but that here, for reasons of space, we limit to mention to its most authoritative authors (Cadei, 2010; Catarsi, 2007; Contini, 2010, 2012; Corsi, Stramaglia, 2009; Formenti, 2000; Gigli, 2016; Iori, 2001; Milani 2018; Pati, 2014; Perillo, 2018; Stramaglia, 2008; Sità, 2005; Ulivieri Stiozzi, 2008).

From this vast field of studies and reflections, in this work we especially refer to the following topics:

\section{- Understanding family phenomena in their context}

Families are active social subjects that evolve, transforming their characteristics, functions, and habits in relation to historical factors and the perspectives of current events (Bertolini, 1996). Therefore, every cognitive act that looks at family realities must consider the wide range of variables that affect relational and transformational processes (Contini, 2006) and adopt a systemic perspective in which «the family is conceived as an organizational structure in charge of mediating and integrating the internal and external needs of the system» (Cusinato, 1988, p. 199).

In this conceptual framework, by observing the living conditions that had characterized pre-Covid-19 Italian parenting, we note some critical issues: work time incompatible with family care; increasingly uncertain and precarious labor market; greater demand for energy towards organizational and managerial aspects of family life at the expense of care for relational issues; few measures for supporting families in the work-family balance (Gigli, 2019). These conditions can be considered as risk factors for the new generations: although they may have their basic needs guaranteed, they risk the deprivation of many other equally important needs for healthy growth and development. These risks are further amplified for the numerous children and adolescents living in a state of poverty and deprivation, in contexts characterized by economic and health conditions, which are below the threshold of acceptability. Estimates of the incidence of educational poverty (Benvenuto, Vaccarelli, Di Genova, 2020) in our country were alarming even before the 
pandemic (ISTAT, 2020b; Save the Children, 2019), and Covid-19 may have only exacerbated them.

- Attention to the qualitative and evolutionary aspects of family relationships in critical events

One of the cardinal assumptions that guide the analyses in the field of family pedagogy is the attention to the quality of relationships, which is also defined in relation to the abilities of families to maintain the identity structure, to keep cohesion, to adequately perform the functions of care and to react to destabilizing instances (Gigli, 2013). These pedagogical reflections conceive an idea of "family well-being" as closely connected to the ability to adapt and to the flexibility through which families manage to cope with situations of imbalance and crisis, without losing their functionality. Therefore, the processes of problem-solving, coping skills, selfempowerment (Levine and Perkins, 1987), and resilience become relevant for families in order to transform critical events into evolutionary events, to mobilize energies, redistribute roles, and negotiate new rules suited to cope with needs.

\section{- Resilience as a process that requires a social dimension}

According to the definition given by Cyrulnik, resilience is the biological, psycho-affective, social, cultural, and educational process that enables the resumption of new development after a traumatic event (Cyrulnik, Malaguti, 2005). In the pedagogical field, there is a tendency to consider resilience as an ecological/systemic process that takes place in the relationship between subjects and their environments (Milani, Ius, 2010); in this dynamic process, the interaction through which people coconstruct their "world of life" plays a crucial role (Serbati, Milani, 2013). Furthermore, it is hypothesized that resilience can be acquired through experience and learning (Malaguti, Cyrulnik, 2005). To effectively cope with a critical event, any family, whatever its morphology is, must be able to draw on both the personal resources of individual members and group resources (Fruggeri, 1999). Therefore, the social resources that one accesses in the communities they belong to, in informal and formal social networks (including educational, social, health and cultural services), are elements of fundamental importance in overcoming crises.

- In emergencies, parents, teachers, and educators play a crucial role in the well-being of children and young people

The strand of studies called emergency pedagogy underlines how, 
in emergencies following catastrophes (of various kinds), the younger generations can react to stress with behaviors

that oscillates between moments of apathy and hyperactivity; isolation/selfclosure; difficulty in concentrating; difficulty with memory, fixing new concepts, and recalling skills; sleep disturbances that can interfere with school performance; and physical symptoms such as headaches, stomachaches, and loss of appetite (Vaccarelli, 2018, p. 358).

When the entire life context goes into crisis, presumably, the adults of reference also suffer a loss of educational functionality: alterations in the relational skills of parents, teachers, and educators are possible, increasing in criticality and educational risk factors (Ibidem, passim). In such situations, it is necessary to support the resilience capacities of adults who have educational functions both by activating specific actions aimed at listening, training, self-empowerment; and by strengthening the sense of community, the network of collaborations, the exchanges between peers.

- Educational alliance between families and educational and school services as a practice of support to parenting and as prevention of distress and family dysfunctionality

In the pedagogical field, particularly in the literature inherent in the socalled "educational alliance" (Contini, 2012; Gigli, 2016; Guerra, Luciano, 2012, 2014; Vandenbroeck, 2010, trad. it. 2011), families are considered active partners in the process of co-education. The educating community, which mobilizes to promote children well-being, has its main actors in the educational and school services, which play a crucial role especially in those territories where the network of cultural, recreational, social offerings for families, children, and youth, is absent and/or impoverished by the economic disinvestment in the recent decades. The practices of the educational alliance have two main purposes: the involvement of parents in their children's school life and the support to parenting. The former also finds its justifications in research which affirms that adequate parental participation can promote school success, increase individual and social well-being, boost self-esteem, improve classroom behavior, and facilitate interpersonal and social skills (Ballen, Moles, 1994; Epstein, 1991; Sui-Chu, Willms, 1996; Wentzel, 1998). But the emphasis on such parental involvement risks being counterproductive if we do not compensate, with appropriate measures, the serious risk of penalizing and marginalizing the 
children of parents who, temporarily or permanently, fail to respond to the many and complex demands of the educational system: in these cases, the family can become an additional obstacle to school and personal success and a brake on the social elevator (Gigli, 2016).

On the parenting support front, a pedagogical intervention can intervene to facilitate the change of attitudes and behavioral patterns, in the direction of acquiring greater critical awareness of the educational role (Gigli, 2007). Early childhood education services and schools can intervene on both fronts in ordinary situations, but above all should they do so in emergency. Educators, teachers, pedagogues can become «guardians of resilience» (Cylulnik, 2005, passim) if adequately supported with specific training tools and concrete project resources.

\section{Literature review on families, children, and educational and school services in Covid-19}

Currently (February 2021), completed and published studies on the impact of the pandemic on families, children, and educational and school services are fewer than those that will be accessible in the forthcoming months. In fact, there are many surveys carried out in various fields both at the national and international level, but whose results are not yet available; we have considered the results of some surveys (probably the first ones) involving parents and education professionals, carried out during the period of the onset of the pandemic and the consequent period of restrictions imposed by national governments with different timing (the so-called "lockdown" that in Italy lasted from March to May 2020).

In the first group of researches, which involved parents during the quarantine, we find four Italian surveys (Bosoni, Bramanti, Merlo, Tomisich, 2020; Gigli, 2020; Mantovani, Bove, Ferri, Manzoni, Cesa Bianchi, Picca, 2021; Spinelli, Lionetti, Pastore, Fasolo, 2020; Tiberio, Fagioli, Carrus, Mastandrea, Fiasco, De Luca, Santamaria, 2020); research which took place in Turkey (Uzun, Karaca, Metin, 2020); another one in the United States, Norway, and Sweden (Pramling Samuelsson, Wagner, Ødegaard, 2020); another one in the United States (LaBrenz, Baiden, Findley, Tennant, Chakravarty, 2020); another one in Saudi Arabia (Andejany, Qutah, Alwajeeh, Msallam, Alyamani, 2020); and one in China (Wang, Pan, Wan, Tan, Xu, Ho, 2020).

These surveys, though developed in heterogeneous disciplinary areas and contexts, have some aspects in common: they were conducted 
during lockdowns, they were carried out through an anonymous online survey, and they obtained a homogeneous sample in terms of the type of respondents (predominantly women, native, highly educated, married or cohabiting, working).

In the second group, we find research that involved educational professionals (teachers, educators, pedagogues) to explore the phenomenon of distance learning and the quality of relationship and communication between schools and families (Chieregato, 2021; Soriani, 2021; Pileri, 2021; Scarpini, 2021; Dýrfjörð, Hreiðrasdóttir, 2020).

In the group of surveys focusing on family life during lockdown, it is possible to find recurrent and homogeneous data on the following themes (of which we present a summary; for more details, see the complete contributions):

\section{- Parental stress and work-family life balance issues}

In all studies, it is evident that an effect of the healthcare restrictions imposed by the pandemic is the increase in parental workload and the struggle to reconcile it with work commitments (both for those who worked from home, and those who went to the workplace). In those countries where educational and school services were closed for some months, the phenomenon was of greater impact. The most evident difficulties manifested by the participants of the various surveys are: concern about the future and the loss of economic stability; difficulties in managing daily life and having to take care of their children's learning; not finding space and time for themselves; not having a social life and not being able to spend time in contact with nature. These data are more relevant for mother respondents than for father respondents.

\section{- Mood in family relationships}

Despite the forced cohabitation, no research has shown an increase in conflicts or feelings of intolerance. On the contrary, in the first phase of the pandemic, the experience of cohesion and emotional closeness seems to have increased. In some cases, the increase in time spent together had a positive effect on the possibility of communicating more and devoting more attention to each other. As far as sharing care work between the genders is concerned, in some cases, there is a growth in paternal presence in these aspects, which historically have been a prerogative of the mother. 
- The couple as a protective factor

Having a cohabiting partner with whom to share the concerns and the burden of family care work seems to be a resource, as reported by the majority of participants (who in all surveys are predominantly part of a nuclear family). There are no data available on the impact of the pandemic in households with different structures (single-parent, divorced, reconstructed). Given that in the research cited above, there were no specific findings on the increase in the phenomena of intra-family violence: the real impact of the pandemic on this specific aspect needs to be further investigated.

\section{- Transformations in parent-child relationships and children's well-being}

Families with younger children report higher levels of stress, probably due to the increased and continuous demand for attention and surveillance. Some studies point to the spread of greater emotional closeness between parents and children; adults' desire to protect children from experiences of anxiety and fear; greater attention to the renegotiation of family and educational rules; attempts to empower children. Other surveys, on the other hand, underline the psychological risks to which the youngest children have been exposed, for different reasons: because of the objective danger to their health; because of the social distancing and greater isolation from their peers; because of the deprivation of extra-familiar educational environments; because of the repercussions of parents' stress on them. We also hypothesize an increase in the amount of time spent by young people, even very young ones, in front of digital devices and their deprivation of bodily experiences and contact with nature.

\section{- Protective factors and resilience}

The resources that are most frequently indicated by the participants to these researches as being useful for overcoming the emergency phase are: their emotional and relational competence, the possibility of sharing with others the experiences and concrete aspects of daily life, the chance to access to information through ICT, the possibility of maintaining a collaborative relationship with the school and early childhood services, the possibility of enjoying outdoor and natural environments. In the review of research that was carried out with the involvement of professionals in the educational sector (also in the first period of the pandemic), we find results of both qualitative surveys (focus groups) and quantitative approaches (questionnaires). Given the heterogeneity of the contexts 
that these studies refer to, it is complex to draw generalizable considerations; however, it is possible to outline some data that are common to all the surveys carried out in Italy (where schools were closed during lockdown), and in those carried out in countries where schools were not closed (e.g. Norway, Iceland, United States), which partly reflect the situation of Italian schools at the first reopening (September 2020).

In the surveys carried out in Italy (Soriani, Scarpini, Pileri, Chieregato, Gigli, 2021) the following results emerge:

- Teachers' difficulty in reaching all their students through distance learning (DaD or READ)

These problems occurred especially with children of foreign origin (because of language barriers) and with the children of those parents who, for various reasons, were unable to assist them in connections (digital divide). In fact, the majority of responding teachers affirm that parental presence and mediation were fundamental to the success of distance learning activities (Soriani, Scarpini, 2021). The lack of digital skills in parents has seriously compromised the educational continuity of their children. Another interesting fact is the motivation that professionals stated they felt in attempting to carry out their work at a distance: the main drive was to «maintain a relationship with the class group and with the individual pupils (more than $90 \%$, a figure that tends to rise to $98 \%$ if we consider only the Preschool group); less than $1.4 \%$ stated that they were driven primarily by the need to continue presenting topics» (Scarpini, 2021, p. 175).

\section{- Needs for information and maintenance of the educational relationship through ICT}

The experiences narrated both by professionals and parents confirm the need to strengthen and restructure the flow of communication, disrupted by the pandemic. Considerations on this aspect (relative to both the closure phase and those hypothesized for the reopening) confirm that to deal with the lack of direct contact with families, schools and educational services must equip with technological tools and environments that facilitate communication in the perspective of strengthening the educational alliance (Gigli, 2021; Pileri, 2021; Soriani, 2021). While considering the "face-to-face" relationship with families better than the one mediated by a digital tool, «teachers generally consider the communicative exchanges with families that take place in official digital 
contexts as more useful than those that take place on unofficial ones» (Soriani, 2021, p. 140). The lack of provision of official communication tools and channels (e.g., Padlet App, Classroom, from the email list, official classroom Whatsapp chats) in schools and early childhood education services poses a risk to the quality of the educational alliance, compromises the flow of information, and facilitates the proliferation of unofficial communication environments (parental chats) that can be grounds for dispersion, redundancy, and distortion of information (Gigli, 2021; Soriani, 2021).

\section{- The introduction of new professional competencies}

According to the opinions of the surveyed professionals, with the pandemic some competencies that were considered innovative for teachers and educators have become current. It was not only a matter of possessing the technological skills necessary to autonomously carry out the educational work at a distance but also of reviewing some founding aspects of the methodological coordinates and the values backgrounds useful to orient the redesign.

For an experience such as the lockdown to not only influence us but also teach us, one must constantly train their active listening, creative and divergent thinking, be open to new looks and new resources, not be afraid to take risks, albeit within a clear ethical framework. Participation, flexibility and the ability to work in close connection with the territory are necessary (Chieregato, 2021, p. 155).

\section{- The centrality of the collegial dimension and training}

Another effect that Covid-19 seems to have provoked is the new emphasis to the collegial dimension of educational work and the need for ongoing training. One of the most recurrent motivations in support of these two instances is that "one cannot rethink themselves professionally alone": in this sense, therefore, where these two conditions were already present before the pandemic, the work of redesigning was easier and more functional; vice versa, where these dimensions appeared neglected, there were situations of dysfunctionality and scarce responsiveness to change (Chieregato, 2021; Gigli, 2021).

Research conducted in countries where government measures have not declared the closure of schools in the first half of 2020 shows a similar picture to those conducted in Italy during the summer reopening (of 
0-6 education and recreation services) and during the fall school reopening. The studies that were carried out in Iceland on the opinion of preschool workers on the consequences of keeping these schools open shows that, when asked "How do you feel in this situation?", The vast majority said they felt proud $(57 \%)$, but people also said they were worried $(43 \%)$ or felt defenseless $(32 \%)$.

Others mentioned feelings of anxiety (31.5\%), gratitude (29.5\%), indifference (8.6\%), anger (8.5\%), and, finally, joy (7.2\%) (Dýrfjörd, Hreiðrasdóttir, 2020, see in particular p. 213). The perception of being "frontline workers" on the one hand has reinforced the ethical and socially useful aspect of educational work, and on the other hand, made them feel the burden of being exposed to health risks that are difficult to control. The major difficulties declared by these professionals were: the management of health protocols in the educational environments (physical distancing, disinfection, etc.); the respect of healthcare norms from parents; a large number of groups of children to manage, which is hardly sustainable with the numerical ratios in force. On the other hand,

the reduced number of children has also allowed us to give some children more time than usual and take better care of them. There are quite a few who are much more willing to come to preschool now than usual, and they also feel a little better (Dýrfjörð, Hreiðrasdóttir, 2020, p. 114).

Many teachers, internationally, agree with the need for more advanced planning in preparation for future crises (Pramling Samuelsson, Wagner, Eriksen Ødegaard, 2020).

\section{The research}

The present research was born from the collaboration between the Center for Educational Research on Children and Families (CREIF) of the Department of Educational Sciences, University of Bologna, and the Pedagogical Coordination of the Municipalities of Bassa Romagna. After a training course for teachers and educators on the pedagogical orientations to redesign the reopening of services in September 2020, we had the idea to monitor the opinion of parents through a survey, which was carried out between 22/12/2020 and 22/1/2021 and was open to all families with children enrolled in early childhood education services. 


\subsection{The context}

The results of this survey are connected to two main factors: on one side, the pandemic situation at the time of the survey and in the three months preceding it; on the other side, the educational and organizational proposal by the crèches and preschools in the area. Regarding the first point, it is worth remembering that in Italy between October 2020 and January 2021 there was a "second wave" of the spread of the virus that led the Government to issue restrictive decrees for the entire population (restriction of freedom of movement, the prohibition of assembly, mandatory use of personal protective equipment, etc.). Despite the closure of secondary schools and universities (which have continued through distance learning - DaD), elementary school, preschools, and crèches have continued their activities in presence; they adopted a highly articulated prevention protocol that, to keep the physical distance, has forced the redesign of environments and schedules, educational programming and modes of relationship between parents and teachers (the assemblies of parents, entering through the same school spaces, teachers' meetings in presence, working with different groups of children... Were forbidden). To deal with the change, while respecting the new organizational structure, a great work has been done to allow the educational and auxiliary staff to safeguard their professional mandate, to work in safety conditions, to maintain the quality standards of the educational proposals, to strengthen the educational alliance with families, to focus on children's needs (needs to settle in, to explore and enjoy stimulating experiences, to develop meaningful relationships with adults and peers, to play and be outdoors, to live in serene relational environments). Many resources have been absorbed by the management of the healthcare aspects of daily life and the tracking of suspected contagions, but in this context, professionals have tried to keep the pedagogical dimension in the foreground.

Despite the considerable challenge, the work of redesigning has produced some innovative practices, both in terms of the management of groups of children and in terms of the relationship between teachers and parents, as well as in the care of the collegial dimension of teamwork.

Since we cannot go into detail about all the undertaken measures, we would like to point out some of the most relevant practices: the provision of official technological communication for all parents; the regular scheduling of individual meetings with parents; the organization of parent's assemblies. 


\subsection{Goals and research questions}

The research questions arose from wondering about the impact of Covid-19 on everyday family life, on parental experiences, and the educational alliance between teachers and parents. We wanted to investigate:

- the level of difficulty and discomfort experienced by families in managing their children at home and in school life;

- parents' needs to adequately carry out their role;

- the resources and the protective factors they could benefit from;

- parents' representations of the difficulties experienced by their children;

- their satisfaction with the educational offerings of the crèches and preschools, and with the actions taken by the pedagogical coordinators;

- the quality of technology-mediated communication and children's use of ICT.

\subsection{The survey: instrument and the sample}

A questionnaire was designed specifically for this study. It consists of 33 closed-ended questions organized into three sessions:

- the first one is dedicated to personal information, housing and working conditions, household composition, and the characteristics of the group of people living together during lockdown;

- the second one is dedicated to investigating the new habits, experiences, needs, resources, the emotional mood in the cohabiting family unit, and parenting difficulties;

- the third one focused on the school life of a single child, on the encountered difficulties, on the actions taken by the school to facilitate the educational alliance, and on the level of parental satisfaction with services.

Data were collected through an online survey. With the support of the group of Pedagogical Coordinators of the Municipalities of Bassa Romagna', the information about the survey and the link to the question-

${ }^{9}$ Especially, we would like to thank Dr. Cristiana Santinelli and Dr. Ernesto Sarracino, Pedagogical coordinators of early childhood education services. The italian $\mathrm{Mu}$ nicipalities involved in the survey are: Alfonsine, Bagnacavallo, Conselice, Cotignola, Fusignano, Lugo, Massalombarda, Santagata sul Santerno. 
naire was sent to all the families enrolled in the early childhood education services of the municipality $(841,520$ of whom in crèches and 320 in preschools), through the official communication channel (i.e. the already mentioned app. Padlet). The collaboration with the Social Services Office was useful to support the participation of families who do not have adequate technological or linguistic tools.

Overall, 178 families responded to the questionnaire, with a response rate of $21.2 \%$.

Although unlike what usually happens in web surveys, the target population was well defined, we are aware that the self-selection of the respondents and the non-responses might create some distortions that invite us to maintain a certain caution in the presentation of the results of the research that, however, has mainly an exploratory purpose.

The profile of the respondents confirmed the fact that it is mainly women who take care of children in Italy: $93.2 \%$ are female. Mediumhigh educational level prevailed: $47.5 \%$ had a high school/professional diploma, $42.4 \%$ a degree or postgraduate degree, $10.2 \%$ a compulsory school diploma. $91.0 \%$ have Italian citizenship. Moreover, $93.8 \%$ of the respondents are married or live together within a civil partnership.

At the time of the interview, $79.8 \%$ live at home with one adult and $14.6 \%$ with two adults. The percentage of those who live with more than two adults is very low $(5.1 \%)$.

Considering the target population of the interview, it is not surprising that $46,6 \%$ live with an underage child, $44.9 \%$ with two, $6.7 \%$ with three, and $1,7 \%$ with four.

$54.5 \%$ have at least one child aged 0 to 3 years. $50 \%$ have at least one child aged between 3 and 6 . The percentage of families with older children is gradually decreasing (the considered age groups are 6-10, 11-14, 15-18, more than 18).

In terms of employment, $79.8 \%$ are employed, $71.9 \%$ of whom are continuously employed. $57.9 \%$ are full-time employees, $30.0 \%$ parttime employees, $10.0 \%$ self-employed, and only $2.1 \%$ have other employment relationships.

According to the majority of respondents (69.5\%), the Covid-19 health emergency did not lead to a change in their workplace, in the sense that they are going to work as before. $20.6 \%$ work partially from home and $7.8 \%$ work totally from home.

Most of the interviewed households have more than one stable income $(61.2 \%)$ or one stable income $(20.2 \%)$. There is also $12.4 \%$ who have one stable income and one non-stable income. $5.1 \%$ have one or 
more non-stable incomes. Only 1.1\% have no income at all. $70.2 \%$ think that their financial situation is quite adequate and $10.7 \%$ very adequate. On the other hand, $17.4 \%$ define it as not very adequate and only $1.7 \%$ not adequate at all.

Only $1.7 \%$ of the respondents live in a house of less than 60 square meters. $48.9 \%$ live in a house of more than 100 square meters. The remaining were distributed between those living in an 80-100 square meters house $(31.5 \%)$ and those living in a $60-80$ square meters house $(18.0 \%)$.

Lastly, as many as $92.1 \%$ have an outdoor space attached to their home (garden, terrace, courtyard, etc.).

Therefore, most respondents show some very precise traits: they are female, Italian citizens, with a medium-high education level, they are employed, and they live in a household that, despite the healthcare emergency, has one or two stable incomes and a financial situation that they consider quite or very adequate.

Since the research has a descriptive aim, the data analysis is mainly based on the frequency distribution.

Given the homogeneity of the sample, rather than focusing on the single sociodemographic variables, we decided to verify to what extent the perception of one's financial situation (introducing a dichotomy between those who define it as a little adequate or not at all adequate and those who define it as quite or rather adequate) affects family life and whether there are differences in the relationship with early childhood education services depending on the age of the child (0-3 and 3-6). Chisquare test was used (significance level 0,05\%). We anticipate that these variables resulted less relevant than we expected, especially the financial situation one.

\section{Data Analysis}

4.1. Section 2: new habits, experiences, needs, resources, the emotional mood in the cobabiting family units, and parenting difficulties, and resources

The first question in this session has the aim to monitor parents' personal experiences during the pandemic period.

Parents most frequently, though not consistently, experienced: anxiety, helplessness, anger/frustration, isolation/solitude, and distrust. As 
Tab. 1 - Since the outbreak of the Covid-19 pandemic, how often have you felt $(\%)$

\begin{tabular}{|c|c|c|c|c|c|c|c|}
\hline & $\begin{array}{c}\text { Never/ } \\
\text { almost } \\
\text { never }\end{array}$ & $\begin{array}{l}\text { Some- } \\
\text { times }\end{array}$ & Often & $\begin{array}{l}\text { Very } \\
\text { often }\end{array}$ & $\begin{array}{l}\text { Con- } \\
\text { stantly }\end{array}$ & Total & $\mathrm{N}$ \\
\hline Anxiety, worry & 12.4 & 42.7 & 27.5 & 14.0 & 3.4 & 100.0 & 178 \\
\hline Rage, frustration & 21.3 & 40.4 & 26.4 & 10.7 & 1.1 & 100.0 & 178 \\
\hline Powerlessness & 15.2 & 36.5 & 32.0 & 12.4 & 3.9 & 100.0 & 178 \\
\hline $\begin{array}{l}\text { Loss of control of } \\
\text { emotional state }\end{array}$ & 53.4 & 33.1 & 7.3 & 5.6 & 0.6 & 100.0 & 178 \\
\hline Depressive feelings & 75.3 & 18.0 & 4.5 & 1.7 & 0.6 & 100.0 & 178 \\
\hline $\begin{array}{l}\text { Decision making } \\
\text { difficulties }\end{array}$ & 53.9 & 30.9 & 10.7 & 3.9 & 0.6 & 100.0 & 178 \\
\hline Isolation, loneliness & 38.8 & 39.3 & 14.0 & 5.6 & 2.2 & 100.0 & 178 \\
\hline Distrust & 24.7 & 48.3 & 15.7 & 9.0 & 2.2 & 100.0 & 178 \\
\hline
\end{tabular}

noted in Table 1, depression, loss of emotional control, and difficulty in making decisions are infrequent.

The second question in this section is: In your opinion, how much discomfort/difficulty is there in your family because of the emergency?

The data show that, according to participants, the level of difficulty/ discomfort experienced in their family is low on average, although nearly half of them report having experienced difficulty/discomfort to some extent (Figure 1). These data are likely affected by the composition of the sample that responded to the questionnaire: they live in a stable economic situation, the greater number of them live in households with a double income, they are in couples, living in large houses and with outdoor spaces available.

The following question helps to better understand the extent of the experienced difficulties.

The data show that the greatest difficulties are related to uncertainty about the future and the impossibility of making plans, to the balance between professional and family work, and the management of children's school life (Table 2). At lower levels, we find the management of organizational and hygienic/healthcare aspects for the prevention of Covid-19 or for taking care of sick relatives. A little difficulty is found in the economic aspects and in observing the restrictive regulations. 


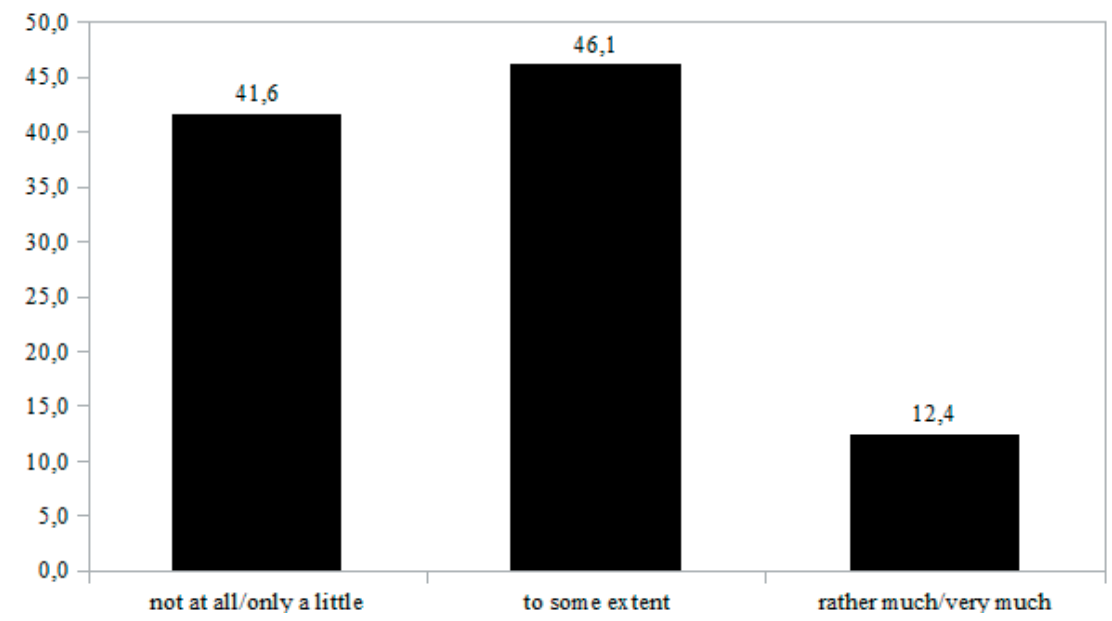

Fig. 1 - In your family, bow much discomfort/difficulty do you think it is due to this emergency? (\%)

Tab. 2 - In your family, how much the Covid-19 emergency has generated difficulties concerning $(\%)$

\begin{tabular}{|c|c|c|c|c|c|}
\hline & $\begin{array}{l}\text { Not at } \\
\text { all/only } \\
\text { a little }\end{array}$ & $\begin{array}{c}\text { To } \\
\text { some } \\
\text { extent }\end{array}$ & $\begin{array}{c}\text { Rather } \\
\text { much/ } \\
\text { very much }\end{array}$ & Total & $\mathrm{N}$ \\
\hline Organizational aspects & 45.5 & 44.9 & 9.6 & 100.0 & 178 \\
\hline Managing emotional aspects & 37.1 & 46.6 & 16.3 & 100.0 & 178 \\
\hline $\begin{array}{l}\text { Management of health/hygiene } \\
\text { aspects }\end{array}$ & 52.2 & 31.5 & 16.3 & 100.0 & 178 \\
\hline Economic aspects & 62.4 & 26.4 & 11.2 & 100.0 & 178 \\
\hline $\begin{array}{l}\text { Insecurity in planning for the } \\
\text { future }\end{array}$ & 16.9 & 46.1 & 37.1 & 100.0 & 178 \\
\hline Balancing work and family & 33.7 & 42.7 & 23.6 & 100.0 & 178 \\
\hline Managing children's school life & 32.0 & 46.6 & 21.3 & 100.0 & 178 \\
\hline $\begin{array}{l}\text { Observance of health/hygiene/ } \\
\text { physical rules }\end{array}$ & 46.1 & 36.0 & 18.0 & 100.0 & 178 \\
\hline
\end{tabular}

To monitor parents' perceived needs, we asked what they needed most. Parents respond on higher levels to following the options (Table 3): having a social life, being outdoors and doing activities in nature, hav- 
Tab. 3 - As a parent, right now, how much do you feel the need to (\%)

\begin{tabular}{|c|c|c|c|c|c|}
\hline & $\begin{array}{l}\text { Not at } \\
\text { all/only } \\
\text { a little }\end{array}$ & $\begin{array}{c}\text { To } \\
\text { some } \\
\text { extent }\end{array}$ & $\begin{array}{c}\text { Rather } \\
\text { much/ } \\
\text { very much }\end{array}$ & Total & $\mathrm{N}$ \\
\hline More space and time for myself & 25.8 & 52.8 & 21.3 & 100.0 & 178 \\
\hline $\begin{array}{l}\text { More help from my partner in } \\
\text { managing family work }\end{array}$ & 58.4 & 29.8 & 11.8 & 100.0 & 178 \\
\hline External help & 64.6 & 28.1 & 7.3 & 100.0 & 178 \\
\hline $\begin{array}{l}\text { More dialogue with educational } \\
\text { staff and/or teachers }\end{array}$ & 45.5 & 47.2 & 7.3 & 100.0 & 178 \\
\hline $\begin{array}{l}\text { Hanging out with friends, } \\
\text { having a social life }\end{array}$ & 7.3 & 40.4 & 52.2 & 100.0 & 178 \\
\hline $\begin{array}{l}\text { Being outdoors, doing activities } \\
\text { in nature }\end{array}$ & 11.8 & 39.9 & 48.3 & 100.0 & 178 \\
\hline $\begin{array}{l}\text { Talk with people who can give } \\
\text { me advice and support me }\end{array}$ & 39.9 & 36.0 & 24.2 & 100.0 & 178 \\
\hline $\begin{array}{l}\text { More collaboration from my } \\
\text { children }\end{array}$ & 64.0 & 28.7 & 7.3 & 100.0 & 178 \\
\hline More economic possibilities & 41.6 & 41.0 & 17.4 & 100.0 & 178 \\
\hline
\end{tabular}

ing more dialogue with educational staff. The answers with medium levels were: having more time and space for themselves; engaging with people who can give them advice. The lowest levels of difficulty were attributed to having more collaboration from children (perhaps because they are young), receiving help from people outside the family, and getting financial help. Even the need to have more help from the partner (despite the sample is predominantly female) does not seem to be particularly felt.

To better understand the level of difficulty experienced in carrying out their parental functions, we asked them, "In this situation, what makes you feel most uncomfortable in your relationship with your children". The answers were:

- answering their questions regarding the bealthcare emergency and its consequences: rather much/very much $5.1 \%$; to some extent $23 \%$; not at all/only a little $71.9 \%$;

- managing time and space at home: rather much/very much $13.5 \%$; to some extent $45.5 \%$; not at all/only a little $41 \%$; 
- taking care of school life: rather much/very much 4.5\%; to some extent $30.3 \%$; not at all/only a little $65.2 \%$;

- managing the emotional and relational dynamics within the family: rather much/very much $11.8 \%$; to some extent $47.8 \%$; not at all/only a little $40.4 \%$;

- managing their use of new technologies (wifi networks, devices, phones, connection times, etc.): rather much/very much $9.6 \%$; to some extent $27 \%$; not at all/only a little $63.5 \%$;

- their isolation from peers: rather much/very much $33.1 \%$; to some extent $48.9 \%$; not at all/only a little $18 \%$;

- the impossibility of having external help (grandparents, baby sitters, etc.): rather much/very much $20.8 \%$; to some extent $31.5 \%$; not at all/only a little $47.8 \%$;

- their continuous request for attention: rather much/very much $16.3 \%$; to some extent $55.1 \%$; not at all/only a little $28.7 \%$;

- the increase in their sedentary lifestyle: rather much/very much $18 \%$; to some extent $44.4 \%$; not at all/only a little $37.6 \%$;

- making sure they respect healthcare regulations when they go out: rather much/very much $8.4 \%$; to some extent $30.3 \%$; not at all/only a little $61.2 \%$;

- not being able to be in contact with nature: rather much/very much $28.1 \%$; to some extent $49.4 \%$; not at all/only a little $22.5 \%$.

By observing the overall scores of the levels of difficulty indicated by the respondents, we can understand that these parents do not perceive to have had any problems in carrying out their parental functions during the pandemic (low level of difficulty 52.8\%; a medium level of difficulty $39.3 \%$; high level of difficulty $7.9 \%$ ). However, through more careful analysis, the aspects that were experienced as most critical are the isolation of children from their peers, the lack of contact with nature, the management of relational dynamics and space within the family, the increase in their sedentary lifestyles, and their continuous demand for attention. Other aspects do not raise problems for the parents of the sample, not even the management of the use of technologies, school life, or making them observe the healthcare regulations out from home.

The following question focuses on understanding the resources that parents perceived as helpful in coping with the emergency.

As can be seen (Table 4), consistently with the answers obtained in other questions of the survey, one of the resources that have been considered as most important is to be able to draw on individual psychological 
Tab. 4 - How much do the following resources help you to cope with this emergency? $(\%)$

\begin{tabular}{|c|c|c|c|c|c|}
\hline & $\begin{array}{l}\text { Not at } \\
\text { all/only } \\
\text { a little }\end{array}$ & $\begin{array}{c}\text { To } \\
\text { some } \\
\text { extent }\end{array}$ & $\begin{array}{c}\text { Rather } \\
\text { much/ } \\
\text { very much }\end{array}$ & Total & $\mathrm{N}$ \\
\hline $\begin{array}{l}\text { One's own psychological } \\
\text { resources }\end{array}$ & 14.6 & 52.2 & 33.1 & 100.0 & 178 \\
\hline The presence of loved ones & 20.8 & 47.8 & 31.5 & 100.0 & 178 \\
\hline Concrete resources & 12.9 & 51.1 & 36.0 & 100.0 & 178 \\
\hline Resources offered by the web & 37.6 & 47.8 & 14.6 & 100.0 & 178 \\
\hline $\begin{array}{l}\text { The relationship with children's } \\
\text { teachers/educators }\end{array}$ & 29.8 & 59.0 & 11.2 & 100.0 & 178 \\
\hline
\end{tabular}

resources that were already present in the existential framework of the subjects. In the same way, the presence of loved ones with whom to share concerns and responsibilities is considered a fundamental resource.

Even the chance to use space, material, and economic resources are considered an absolutely facilitating aspect.

Less important, but still considered quite useful, is the possibility to have communicative exchanges with educational and school personnel.

\subsection{Section 3: children's well-being and school life}

In this session, parents were asked to respond only regarding one of their children. The distribution of children by age group was: $38 \%$ from 0 to 3 years old (enrolled in crèches) 61\% from age 3 to age 6 (enrolled in municipal preschools).

When asked, "In your perception, how much has the pandemic caused to your child:", they answered:

- moments of regression: rather much/very much $6.7 \%$; to some extent $30.9 \%$ (mostly for children aged 4-6: 42.5\%); not at all/only little $62.4 \%$;

- difficulties in sleeping and/or eating: rather much/very much $6.7 \%$; to some extent $16.3 \%$; not at all/only little $77.0 \%$;

- difficulties in going out, preferring to stay indoors: rather much/very much $11.2 \%$; to some extent $31.5 \%$ (mostly for children aged 4-6: $42.5 \%)$; not at all/only little $57.3 \%$; 
- discomfort in closed environments, preferring to stay outdoors: rather much/very much $3.9 \%$; to some extent $23.0 \%$; not at all/only a little $73.1 \%$

- difficulties in managing emotions (management of frustration, anger, aggression): rather much/very much $39.9 \%$; to some extent $15.2 \%$; not at all/only a little $44.9 \%$

- difficulties in detaching from reference figures: rather much/very much $16.9 \%$; to some extent $35.4 \%$; not at all/only a little $47.8 \%$;

- problems with socialization: rather much/very much $8.4 \%$; to some extent $26.4 \%$; not at all/only a little $65.2 \%$;

- difficulties in integrating into the school environment: rather much/ very much $7.3 \%$; to some extent $17.4 \%$; not at all/only a little $75.3 \%$. Parents' representations of the difficulties caused to their children by the Covid-19 pandemic show a positive picture. Despite what might have been hypothesized, these preschool children do not express signs of discomfort in either psychophysical aspects or relational dimensions. Some difficulties, though not very frequent, are reported in emotion management and in the problems in going out, preferring to stay at home.

Regarding the use of digital tools, we asked: "In a day without school, how much time does your child spend, on average, in contact with digital devices (computers, smartphones, tablets, television, video games, etc.)?”.

The answers were: up to one hour per day $38.2 \%$; between 1 hour and 3 hours $48.3 \%$; more than 3 hours $13.50 \%$. There is a relationship with the age of the children $(0-3 ; 3-6)\left(\chi^{2}(2)=43.4, \mathrm{p}<.001\right)$. Data on the use of electronic devices by these very young children, on non-school days, indicate that the majority spend between 1 hour and 3 hours (mostly for children aged 3-6: 61.5\%); although 38.2\% spend up to one hour per day (mostly for children aged 0-3: 68.1\%), it is alarming to note that 13.5\% spend more than 3 hours (mostly for children aged 3-6: 19.3\%).

The first question about school life was: "Since the reopening of preschool/crèche (Sept. 2020), your child:". The overall picture that emerges from the answers is substantially positive: $69.9 \%$ affirm that their child has been able to attend regularly; $17.3 \%$ that their child interrupted attendance for short periods of time (less than a week); $8.7 \%$ said their child interrupted attendance for long periods (more than one week); $4.0 \%$ state that their child stayed more time at home than at school.

The data clearly show that, despite the flare-up of the pandemic in Italy (Emilia Romagna was almost always in the so-called "orange zone", meaning there was an intermediate level of risk) in the 4 months of reopening considered (September-December 2020), the majority of 
children were able to attend regularly, with no significant differences between crèche and preschools.

To investigate children's health situation, we asked the following question: "Since the beginning of the school year, how frequently bave the following situations occurred with your child". With no significant differences between crèche and preschool, the answer was:

- he/she stayed home due to illnesses (different from Covid-19): sometimes $16.9 \%$; never $57.9 \%$; once $23.0 \%$;

- he/she stayed home in isolation due to contact (real or presumed) with Covid-19 positive persons: never $71.9 \%$; once $25.3 \%$; sometimes $2.2 \%$;

- he/she stayed home in self-isolation due to family choice (e.g.: to avoid possible exposure to infection, or to protect grandparents, etc.): never $84.3 \%$; once $9.0 \%$; sometimes $3.4 \%$; often $2.2 \%$; very often $1.1 \%$;

- be/she stayed home due to contracting Covid-19: never 98.3\%; once $1.7 \%$;

- he/she was tested for Covid-19 positivity: never $61.8 \%$; once $33.1 \%$; sometimes $3.9 \%$; often $1.1 \%$.

There is a significant relationship with the children's age, but it concerns the not-Covid-19 illnesses $\left(\chi^{2}(4)=19.0, \mathrm{p}<0.001\right)$ : younger children (0-3) stayed home more frequently.

The health situation in this territory (which is located in a region that the government considered as a zone of medium level of healthcare risk during the period of the survey) seems to offer a positive picture: almost all the children have not contracted the disease, only a third have been submitted to a Covid-19 swab, almost none had to stay in quarantine.

A question concerns the initiatives taken by educational services and schools, to adapt school life to the emergency.

Parents' opinions show that, despite the virus, the quality of educational work and relational aspects has remained high (see Table 5). Some particularly interesting data are those on the timely information received by parents regarding both healthcare issues and the pedagogical aspects of educational programming, as well as the efforts made to reach families remotely. Moreover, parents recognize that educational services have modified their times, spaces, and rules to respond more to children's needs than families' ones: we believe that this can be considered an indicator of quality.

The age difference is significant only for two measures: the creation of virtual communication spaces with parents is more widespread for children aged $0-3\left(\chi^{2}(2)=6.95, \mathrm{p}=0.031\right)$; the organizational changes introduced to meet the needs of younger children are greater $\left(\chi^{2}(2)=13.5, \mathrm{p}=0.001\right)$. 
Tab. 5 - How much is your child's crèche/preschool...? (\%)

\begin{tabular}{lccccc}
\hline & $\begin{array}{c}\text { Not at } \\
\text { all/only } \\
\text { a little }\end{array}$ & $\begin{array}{c}\text { To } \\
\text { some } \\
\text { extent }\end{array}$ & $\begin{array}{c}\text { Rather } \\
\text { much/ } \\
\text { very much }\end{array}$ & Total & N \\
\hline $\begin{array}{l}\text { Teachers have created virtual } \\
\text { communication spaces with } \\
\text { parents }\end{array}$ & 21.9 & 52.8 & 25.3 & 100.0 & 178 \\
$\begin{array}{l}\text { Information about the situation } \\
\text { and the hygiene/health rules of } \\
\text { the school }\end{array}$ & 22.5 & 51.1 & 26.4 & 100.0 & 178 \\
$\begin{array}{l}\text { Information about educational } \\
\text { programming }\end{array}$ & 10.1 & 48.3 & 41.6 & 100.0 & 178 \\
$\begin{array}{l}\text { Efforts to help those who do } \\
\text { not have the tools to connect }\end{array}$ & 28.1 & 59.6 & 12.4 & 100.0 & 178 \\
$\begin{array}{l}\text { The organization of the service } \\
\text { has been modified to meet the } \\
\text { needs of the parents }\end{array}$ & 34.3 & 46.1 & 19.7 & 100.0 & 178 \\
$\begin{array}{l}\text { The organization of the service } \\
\text { has been modified to satisfy the } \\
\text { needs of the children }\end{array}$ & 18.5 & 51.7 & 29.8 & 100.0 & 178 \\
\hline
\end{tabular}

The opinion on the use of parents' chats during the pandemic period was monitored with the following question: "In this emergency, how much do you think the use of instant messaging between parents (e.g.: class chats, parents' groups on other platforms, etc.) will help?".

The data highlights that, although many people think they could be useful they are not used correctly (rather much/very much $16.3 \%$; to some extent $35.4 \%$; not at all/only a little $48.3 \%$ ), the great number of participants attribute to these tools some positive functionality. They think that they are extremely useful tools for obtaining information: rather useful/very useful $31.5 \%$; quite useful $56.2 \%$. The opinion on their usefulness in combating isolation and loneliness is different: the majority of respondents do not consider them rather useful/very useful in this sense (rather much/very much $16.3 \%$; to some extent $39.3 \%$; not at all/only a little useful $44.4 \%$ ).

An important question is: "Regarding your communication with teachers and educators, do you think". This question was asking for opinions on the impact of the pandemic on the quality of communica- 
tion between teachers and parents. The data offers an overall positive picture.

For many $(44.9 \%)$, the observation of healthcare restrictive measures (which prohibit in-person assemblies with parents and individual meetings with parents and deny usual daily contact) has severely compromised communicative exchanges; however, the majority of opinions are positive, if we add those who indicate that the pandemic has not compromised communication $(40.4 \%)$ with those who say it has even improved it $(14.6 \%)$.

Closely related to the previous answers, the following question monitored the initiatives taken by pedagogical coordinators and the school staff to adapt the educational services within the pandemic framework: "In the preschool/crèches that your child attends, has the pedagogical coordination activated the following specific initiatives?".

Table 6 shows how, in this context, the pedagogical coordinators have taken care of the educational alliance by activating various forms of communication between teachers and parents.

Obviously, because of health regulations, it was preferred to guarantee remote forms of communication; nonetheless, there were also occasions for face-to-face meetings (with appropriate physical distance and masks), especially in cases of children entering the school for the first time, or the meetings at the beginning of the school year.

Lastly, we asked parents to rate on a scale from 1 (very low) to 5 (very high) their level of satisfaction.

Despite the virus, in this context, it seems that the actions taken by the pedagogical coordinators and by the teachers have borne good fruits

Tab. 6 - In the crèches/preschool your child attends, the pedagogical coordination has activated the following specific initiatives? (\% yes)

\begin{tabular}{lcc}
\hline & $\%$ yes & $\mathrm{N}$ \\
\hline $\begin{array}{l}\text { Face-to-face meetings with parents (meetings, themed } \\
\text { meetings, etc.) }\end{array}$ & 20.8 & 178 \\
$\begin{array}{l}\text { Remote meetings with parents (meetings, themed meetings, } \\
\text { etc.) }\end{array}$ & 82.0 & 178 \\
$\begin{array}{l}\text { In-person individual meetings } \\
\text { Individual remote meetings }\end{array}$ & 14.0 & 178 \\
Setting up a virtual communication environment & 68.5 & 178 \\
\end{tabular}




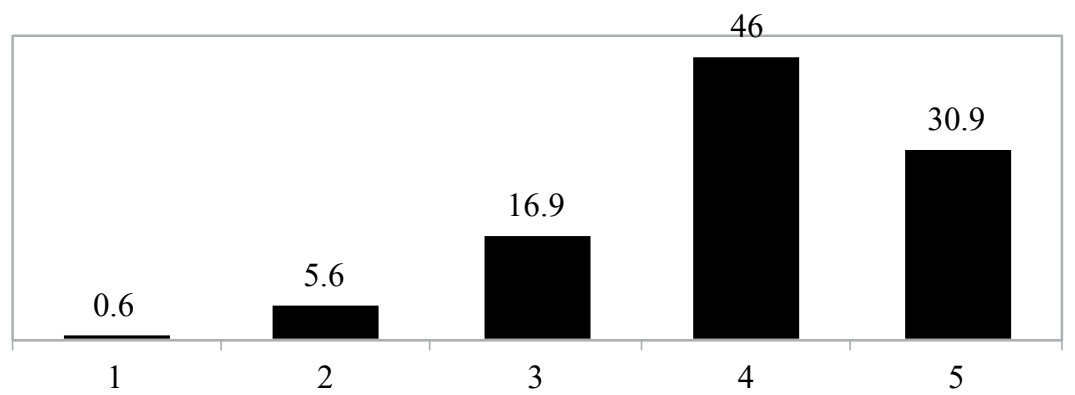

Fig. 2 - During the pandemic, what is your level of satisfaction with the educational service your child attends? Scores from 1 (not at all satisfied) to 5 (completely satisfied) $(\%)$

(Figure 2): the level of parental satisfaction is very high (if we add level 4 responses to level 5 ones, we get $77 \%$ of high satisfaction), and negative opinions are not numerically significant. The relationship with the children's age shows that the satisfaction with the service is higher for those $0-3\left(\chi^{2}(4)=12.2, p=0.016\right)$. However, for both the median is 4 .

\section{Conclusion and implications}

The research involved a sample of 178 parents of children attending crèche and preschool in a specific territory: the municipalities in the area of the Bassa Romagna (Province of Ravenna, Emilia-Romagna Region, Italy). The survey was also created with the idea of being used by professionals working in these educational services, with a double purpose for them: on one side, getting deeper information on parents' opinions on various aspects of the impact of the pandemic on daily life, and, on the other side, understanding to what extent their actions (taken to adapt the schools to the new needs of the pandemic period) have reached the satisfaction of families.

In this geographical area, education and communication practices have been partly modified to guarantee both the quality of the educational proposal and healthcare safety.

This survey serves as feedback from families.

As already mentioned, the sample that responded to the online questionnaire is affected by the limitations of this type of survey and is very homogeneous: predominantly mothers, with a high level of education, 
economic security, and belonging to nuclear families. These responses, therefore, need to be interpreted in the light of this situation, and cannot be generalized or extended to other contexts.

The questionnaire section dedicated to exploring new habits, experiences, needs, resources, the emotional mood within the cohabiting household, and parenting difficulties and resources, gives a picture of substantial positivity: parents, despite being suffering from greater stress and new and more onerous organizational and relational tasks, declare that they have experienced their role rather regularly.

Since these parents do not have any considerable economic or material difficulties, the overall picture is that of resilience in which the greatest problems are uncertainty regarding the future and the impossibility of making plans, finding a balance between professional life and family work, and the management of the children's school life. The greatest difficulties in carrying out the parental role (always indicated on average levels) regard their concerns about children's isolation from their peers, the lack of contact with nature, the management of relational dynamics and spaces within the family, the increase in sedentary lifestyles for children, and their continuous demand for attention.

When asked about their specific parenting needs, the most frequent responses were: having a social life, being outdoors and doing activities in nature, having more dialogue with educational staff.

The main resources they feel they have drawn on to deal with the emergency, on the other hand, are their own psychological and relational resources. Other more concrete resources are also considered important: e.g. having ample domestic space available, outdoor areas where they can stay, and not having economic vulnerabilities.

Also, in the third section of the questionnaire, which was dedicated to monitoring children's well-being and their school life, the answers do not show criticalities: according to these parents, preschool children do not express evident signs of discomfort, psychophysical or relational ones. Some parents reported moderate trouble in their children, related to managing emotions, to difficulties in going out, and to the preference to stay at home.

Perhaps this is evidence that, as hypothesized by emergency pedagogy studies, the ability to have a regular social life in school settings is a real protective factor that increases children's resilience.

Although the data show widespread and rather extended use of electronic devices (on non-school days) by these very young children, this does not seem to particularly worry parents, who don't notice it as a problem. 
Despite the flare-up of the pandemic in Italy in the considered months, the majority of children were able to attend school regularly without health problems: almost all children did not contract the disease, only a third underwent a Covid-19 swab, and almost none had to remain home in quarantine.

The educational services involved in the research seem to have responded adequately to the health emergency, succeeding in adapting their organization to the changed situation and maintaining continuity in communicating with families.

This theme was explored with several questions and the answers show that having activated remote and virtual communication channels, in support of the already established forms of communication, has had good results. The research results, however, are not completely unambiguous: on the one hand, for just over half of the respondents, communication with educators has not been compromised, or has even improved; on the other hand, the lack of opportunities for communication with educators were seen as the main critical issue.

It is possible to hypothesize that the situation of uncertainty and the continuous change in hygienic-sanitary conditions increase the "information hunger" and the perception of never having enough of it, and this need remains regardless of the undertaken communicative actions. This is confirmed by the fact that, in all the questions on aspects related to communication, positive evaluations prevail over negative ones.

Parents' evaluation of the quality of the educational proposal is overall highly positive and this positively repays the efforts made by the professionals; a comforting fact, and an indicator of quality, is that parents recognized the attention paid by professionals to children's needs of the in the pandemic situation.

As expected, being rather common in this type of survey, the most evident critical point of the research is the lack of participation of a greater number of parents. Even though this limit weakens the statistical significance of the research, these data are important as they tell of the fatigue and overload that was experienced by families in this period, accentuated by the problems in work-family balance that was increased by the pandemic.

Another critical issue, rather known and predictable, is the lack of involvement of fathers: unfortunately, despite some positive signs of greater paternal presence in the work of family care, in Italy, it is mainly mothers who take care of their children's school life: this is an issue that needs further work. 
In conclusion, we believe that this survey can contribute to a reflection on some educational aspects that, although they do not appear particularly critical, can still be improved with awareness-raising actions aimed at parents. The first theme, which deserves further study, is that of children's extended use of digital tools, which seems to be an educational risk factor that parents underestimate.

The second issue that deserves attention is the increase in parents' sensitivity to the need for contact with nature, considered important to maintain the psychophysical balance of both adults and children. We believe it is positive that this aspect, abundantly recognized by naturebased pedagogical theories and already experienced in the educational practices of some schools that practice outdoor education, is now given greater importance by families; thus, it can be considered a powerful pedagogical antibody (Borelli, 2021) to reduce educational risks in emergency.

\section{References}

Andejany N., Qutah K., Alwajeeh S., Msallam R., Alyamani D. (2020, August): Parent Child Relationship During COVID-19 in Saudi Arabia Parental History of Trauma and Resilience during COVID-19. Research Square, n.i.n., pp. 1-11.

Ballen J., Moles O. (1994): Strong families, Strong Schools: Building Community Partnerships for Learning. Washington: U.S. Department of Education Press.

Benvenuto G., Vaccarelli A., Di Genova N. (2020): Resilienza e successo formativo per contrastare la povertà educativa. QTimes, a. XI, n. 4, pp. 114-126.

Bertolini P. (1996): La responsabilità educativa. Torino: Il Segnalibro.

Bosoni M.L., Bramanti D., Merlo F., Tomisich M. (2020): La famiglia al tempo del COVID19", (https://centridiateneo.unicatt.it/famiglia-famigliacovid19-la-scuola-al-tempo-del-covid-19\#content: ultima consultazione: 5.2.21).

Borelli C. (2021): La nostra relazione con la natura: dalle cause dell' attuale pandemia agli orizzonti di possibilità quanto mai inattuali dell'educazione esperienziale nature based. In A. Gigli (a cura di): Oltre l'emergenza. Sguardi pedagogici su infanzia, famiglie, servizi educativi e scolastici nel Covid-19. Parma: Edizioni Junior-Bambini, pp. 119-129.

Cadei L. (2010): Riconoscere la famiglia. Strategie di ricerca e pratiche di formazione. Milano: UNICOPLI.

Catarsi E. (2007): Pedagogia della famiglia. Roma: Carocci.

Chieregato N. (2021): La corresponsabilità educativa ai tempi del Covid-19 (e dopo): un riflettore acceso sull'alleanza fra famiglie, scuole e servizi. In A. Gi- 
gli (a cura di): Oltre l'emergenza. Sguardi pedagogici su infanzia, famiglie, servizi educativi e scolastici nel Covid-19, cit., pp. 147-157.

Contini M. (2006): Le famiglie di oggi: problematicità e prospettive di cambiamento. RIEF-Rivista Italiana di Educazione Familiare, 1(2), pp. 28-37.

Contini M. (a cura di) (2010): Molte infanzie molte famiglie. Roma: Carocci.

Contini M. (a cura di) (2012): Dis-alleanze nei contesti educativi. Roma: Carocci.

Corsi M., Stramaglia M. (2009): Dentro la famiglia. Armando Editore: Roma.

Cusinato M. (1988): Psicologia delle relazioni famigliari. Bologna: il Mulino.

DOXA (2020): Emergenza Covid-19: gli italiani tra fragilità e resilienza finanziaria. (http://www.quellocheconta.gov.it/export/sites/sitopef/modules/img/ news/news095/Rapporto-Comitato-Doxa.pdf; data di ultima consultazione: 3.2.21).

Dýrfjörð K., Hreiðrasdóttir A. E. (2020): Keeping Preschools Open during Covid-19: The Employees' Perspective. Sodobna pedagogika/Journal of Contemporary Educational Studies, 71(137), n. 4, pp. 206-222.

Epstein J. (1991): Effects on Student Achievement of Teachers' Practices of Parent Involvement". Advances in Reading and Language Research, n. 5, pp. 261-276.

Formenti L. (2000): Pedagogia della famiglia. Milano: Guerini Studio.

Fruggeri L. (1999): Famiglie. Roma: Carocci.

Gigli A. (2007): Famiglie mutanti. Pedagogia e famiglie nella società globalizzata. ETS: Pisa.

Gigli A. (2013): Oltre la crisi educativa delle famiglie: quali i compiti della pedagogia? Pedagogika, a. XVII, n. 1, 2013, pp. 70-74.

Gigli A. (2016): Famiglie evolute. Capire sostenere le famiglie plurali. Bergamo: Junior.

Gigli A. (2020): Il benessere dei minorenni nei nuclei familiari contemporanei: riflessioni pedagogiche. In E. Macinai, I. Biemmi (a cura di): I diritti dell'infanzia in prospettiva pedagogica. Equità, inclusione e partecipazione a 30 anni dalla CRC. Milano: FrancoAngeli, pp. 155-152.

Gigli A. (2021): Essere genitori durante il lockdown nel Covid-19: i dati di una rilevazione. In A. Gigli (a cura di): Oltre l'emergenza. Sguardi pedagogici su infanzia, famiglie, servizi educativi e scolastici nel Covid-19, cit., pp. $28-48$.

Guerra M. (a cura di) (2012): Dialoghi tra genitori e insegnanti. Una conversazione essenziale per imparare uno dall'altro. Bergamo: Junior.

Guerra M., Luciano E. (a cura di) (2014): Costruire partecipazione. La relazione tra famiglie e servizi per l'infanzia in una prospettiva internazionale. Bergamo: Junior.

Iori V. (2001): Fondamenti pedagogici e trasformazioni familiari. Brescia: La Scuola.

ISTAT (2020a): Situazione e prospettive delle imprese nell'emergenza sanitaria covid-19 (https://www.istat.it/it/files/2020/06/Imprese-durante-Covid-19. pdf; data di ultima consultazione: 23.2.21). 
ISTAT (2020b): Le statistiche dell'ISTAT sulla povertà. Report ANNO 2019. Roma: Istituto Nazionale di Statistica (https://www.istat.it/it/files/2020/06/ REPORT_POVERTA_2019.pdf; data di ultima consultazione: 23.2.21).

LaBrenz C., Baiden P., Findley E., Tennant P.S., Chakravarty S. (2020): Parental History of Trauma and Resilience during COVID-19 (https://www.researchgate.net/publication/343732974; last access: 20.2.21).

Levine M., Perkins D. V. (1987): Principles of Community Psychology. New York: Oxford University Press.

Mantovani S., Bove C., Ferri P., Manzoni P., Cesa Bianchi A., Picca M. (2021): Children "under lockdown": voices, experiences, and resources during and after the COVID-19 emergency. Insights from a survey with children and families in the Lombardy region of Italy. EUROPEAN EARLY CHILDHOOD EDUCATION RESEARCH JOURNAL, 29(1), pp. 35-50.

MEF. (2020): L'impatto del Covid-19 e degli interventi del Governo sulla situazione socio-economica delle famiglie italiane nei primi tre mesi della pandemia (https://www.finanze.gov.it/export/sites/finanze/.galleries/Documenti/ Varie/Nota-tematica-n.-3-Impatto-del-Covid-19-sulla-situazione-socio-economica-delle-famiglie-italiane.pdf; data di ultima consultazione: 23.2.21).

Milani P. (2018): Educazione e famiglie. Ricerche e nuove pratiche per la genitorialità. Roma: Carocci.

MIUR (2020): Commissione Infanzia e sistema Integrato Zero-sei. ORIENTAMENTI PEDAGOGICI SUI LEAD. LEGAMI EDUCATIVI A DISTANZA (https://www.miur.gov.it/orientamenti-pedagogici-sui-legami-educativi-adistanza-per-nido-e-infanzia-lead; data di ultima consultazione: 20.2.21).

Pati L. (2014): Pedagogia della famiglia. Brescia: La Scuola.

Perillo P. (2018): Pedagogia per le famiglie. Milano: FrancoAngeli.

Pileri A. (2021): Infanzie, famiglie, personale dei servizi zero-sei al tempo del Covid-19. Quale co-educazione possibile? In A. Gigli (a cura di): Oltre l'emergenza. Sguardi pedagogici su infanzia, famiglie, servizi educativi e scolastici nel Covid-19, cit., pp. 185-198.

Pramling Samuelsson I., Wagner J.T, Eriksen Ødegaard E., (2020): The Coronavirus Pandemic and Lessons Learned in Preschools in Norway, Sweden and the United States: OMEP Policy Forum. International Journal of Early Childhood, n. 52, pp. 129-144.

Save the Children (2019): Il miglior inizio disuguaglianze e opportunità nei primi anni di vita (https://s3.savethechildren.it/public/files/uploads/pubblicazioni/il-miglior-inizio-disuguaglianze-e-opportunita-nei-primi-anni-di-vita. pdf; data di ultima consultazione: 23.2 .21 )

Scarpini M. (2021): Scuole e famiglie nella didattica a distanza: la voce degli insegnanti. In A. Gigli (a cura di): Oltre l'emergenza. Sguardi pedagogici su infanzia, famiglie, servizi educativi e scolastici nel Covid-19, cit., pp. 105-117.

Sità C. (2005): Il sostegno alla genitorialità. Brescia: La Scuola.

Soriani A. (2021): Le sfide, in termini di inclusione, di una scuola forzata alla non-presenza. Esiti di una ricerca condotta presso un istituto comprensivo del 
territorio Bolognese. In A. Gigli (a cura di): Oltre l'emergenza. Sguardi pedagogici su infanzia, famiglie, servizi educativi e scolastici nel Covid-19, cit., pp.133-144.

Stramaglia M. (2008): I nuovi padri. Macerata: EUM.

Sui-Chu E. H., Willms J.D. (1996): Effects of Parental Involvement on EighthGrade Achievement. Sociology of Education, n. 69, pp. 126-141.

Tiberio L., Fagioli S., Carrus G., Mastandrea S., Marta Fiasco, Daunia De Luca, Chiara Santamaria (2020): La vita in famiglia ai tempi del coronavirus. Una fotografia dell'esperienza delle famiglie in Italia: risultati preliminari di un'indagine online (https://docplayer.it/190321593-La-vita-in-famiglia-ai-tempidel-coronavirus.html; data di ultima consultazione: 23.2.21).

Ulivieri Stiozzi S. (2008): Pensarsi padri. Milano: Guerini e Associati.

Uzun H., Karaca N.H., Metin S. (2021): Assesment of Parent-Child Relationship in Covid-19 Pandemic. Children and Youth Services Review, n. 120, pp. 1-11.

Vaccarelli A. (2018): Educazione in emergenza: l'intervento pedagogico nelle situazioni di catastrofe. In L. Cerrocchi, L. Dozza (a cura di): Contesti educativi per il sociale. Progettualità, professioni e setting per il benessere individuale e di comunità. Milano: FrancoAngeli, pp. 354-365.

Vandenbroeck M. (2010): Educare alla diversità sociale, culturale, etnica, familiare. Trad. it. Bergamo: Junior, 2011.

Wang C., Pan R., Wan X., Tan Y., Xu L., Ho C.S., Ho R.C. (2020): Immediate Psychological Responses and Associated Factors during the Initial Stage of the 2019 Coronavirus Disease (COVID-19) Epidemic among the General Population in China. Int. J. Environ. Res. Public Health, 17(1729), pp. 2-25.

Wentzel K. (1998): Social Relationships and Motivation in Middle School. The Role of Parents, Teachers and Peers. Journal of Educational Psychology, 90(2), pp. 202-209.

WHO (2020): Pandemic Fatigue Reinvigorating the Public to Prevent COVID-19. (https://apps.who.int/iris/bitstream/handle/10665/335820/WHO-EURO2020-1160-40906-55390-eng.pdf? sequence $=3$ \&isAllowed=y; last access: 23.2.21). 